\title{
Urinary fluoride excretion by children 4-6 years old in a south Texas community
}

\author{
Ramon J. Baez, ${ }^{1}$ Martha X. Baez, ${ }^{2}$ and Thomas M. Marthaler ${ }^{3}$
}

ABSTRACT This study evaluated urinary fluoride excretion by school children 4-6 years old who were living in a south Texas rural community that had concentrations of fluoride in drinking water supplies generally around the optimal level. We took supervised collections of urine samples in the morning and afternoon at school, and parents of the participating students collected nocturnal samples. We recorded the beginning and end times of the three collection periods and then determined the urinary volume and urinary flow for each of the periods. We measured urinary fluoride concentrations and calculated the urinary excretion rate per hour. The children had breakfast and lunch provided at the school, where the drinking water contained 1.0-1.3 milligrams/liter $(\mathrm{mg} / \mathrm{L})$ fluoride. Fluoride concentrations in the tested household water supplies, from wells, ranged from 0.1 to $3.2 \mathrm{mg} / \mathrm{L}$ fluoride. The children's average urinary fluoride concentrations found for the day were similar to those for the night, with means ranging from $1.26 \mathrm{mg} / \mathrm{L}$ to $1.42 \mathrm{mg} / \mathrm{L}$. Average excretion was $36.4 \mu \mathrm{g} / \mathrm{h}$ in the morning, $45.6 \mu \mathrm{g} / \mathrm{h}$ in the afternoon, and $17.5 \mu \mathrm{g} / \mathrm{h}$ at night. The lower nocturnal excretion rates are easily explained by low urinary flow at night. Based on the 15 hours of urine collected, the extrapolated 24hour fluoride excretion was $749 \mu \mathrm{g}$. In conjunction with similar studies, the data from this study will help in developing upper limits for urinary fluoride excretion that are appropriate for avoiding unsightly fluorosis while providing optimal protection against dental decay.

Dental fluorosis, whether minor or more noticeable, is the consequence of excessive fluoride intake. Unfortunately, the manifestations of such fluorosis can only be assessed several years

\footnotetext{
University of Texas Health Science Center at San Antonio, Dental School, Department of General Dentistry and World Health Organization Collaborating Center, San Antonio, Texas, United States of America. Send correspondence to: Ramon J. Baez, Department of General Dentistry Dental School, University of Texas Health Science Center at San Antonio, San Antonio, Texas 78229-3900, United States of America; e-mail: baez@uthscsa.edu

2 University of Texas Health Science Center at San Antonio, Dental School, Department of Community Dentistry, San Antonio, Texas, United States of America.

3 University of Zurich, Centre for Dentistry, Clinic for Preventive Dentistry, Periodontology and Cariology, Zurich, Switzerland.
}

after the individual has been exposed to higher-than-recommended fluoride levels (1). This situation was a minor disadvantage as long as waterborne fluoride was virtually the only source of supplemental fluoride. However, other fluoride sources have become available, with the increasing use of fluoridated dentifrices beginning in the 1960s and of such other caries-preventive fluoride preparations as rinses used at home beginning in the 1980s $(2,3)$. Given those changes, the World Health Organization (WHO) now points to urine, plasma, and ductal saliva as "contemporary" biomarkers of fluoride exposure (1).

Both urinary flow and $\mathrm{pH}$ are involved in regulating renal clearance of fluoride from blood (4). Urinary fluoride concentrations obtained from single "spot" samples are the most accessible indicator of fluoride exposure. However, mere concentrations are not a reliable marker. Fluoride may be diluted by high urinary flow, or high concentrations may occur when little fluid is drunk, resulting in low urinary flow. Basically, urinary fluoride concentrations do not provide a direct measure of fluoride excreted via urine. However, urinary excretion does correlate very well with the plasma fluoride concentration (5), which is regarded as the most valid indicator of the fluoride supply to the organism. In field studies, timed urinary collections are obviously easier to obtain than the 
blood samples needed to determine plasma fluoride.

In the early days of water fluoridation, urinary fluoride concentrations were the main object of study. Nevertheless, since the late 1980s an increasing number of studies have been carried out using time-controlled collections to assess the actual amount of fluoride excreted in the urine. Many of the studies have focused on schoolage children because of the convenient access and the possibility to closely supervise uninterrupted collection of urine $(6,7)$. One summary on fluoride exposure and urinary fluoride indicated that the higher the levels of exposure, the higher were the excretions (8).

Water fluoridation continues to be the most successful and thoroughly investigated systemic use of fluoride for caries prevention. However, few urinary excretion data are available from areas with optimally adjusted water fluoridation. To predict dental fluorosis it would be important to have data from many populations using drinking water at and around optimal concentrations. There are also no data on urinary fluoride excretion by children living in rural communities with no central water supplies and where concentrations of fluoride may be optimal or above optimal. In the long run, developing standards for fluoride excretion will allow predictions of whether the current level of fluoride exposure will result in an acceptable frequency and severity of dental fluorosis.

Studies in children aged 2 to 5 are key because the risk of developing fluorosis in incisors is highest at this age. New fluoridation standards will ensure that the total fluoride intake is adequate for optimal protection against dental caries but with minimum risk of producing unsightly fluorosis.

This descriptive study aimed to assess urinary fluoride in a community whose water supplies contain fluoride in concentrations moderately higher than recommended. The age of the children studied, 4 to 6 years old, allowed supervised collections during the day, which is normally difficult in children younger than that. A second aim of the study was to help develop fluoride excretion standards for this age group.

\section{MATERIALS AND METHODS}

We selected the community of San Isidro, Starr County, Texas, for our study, which was conducted in March 1997. San Isidro is a rural community located approximately 30 miles north of the border between Mexico and the United States of America. The area has a climate that can be characterized as tropical or subtropical. The area's mean daily maximum temperature is $92^{\circ} \mathrm{F}$ $\left(33.3^{\circ} \mathrm{C}\right)$ during the summer months of July and August and $70^{\circ} \mathrm{F}\left(21.1^{\circ} \mathrm{C}\right)$ in the winter months of December and January; the corresponding mean daily minimum temperatures are $75{ }^{\circ} \mathrm{F}$ $\left(23.9^{\circ} \mathrm{C}\right)$ and $52^{\circ} \mathrm{F}\left(11.1^{\circ} \mathrm{C}\right)$.

San Isidro has some 2500 inhabitants. The closest city with a community water system is Rio Grande City, which is the county seat and is located on the border with Mexico. Most families in San Isidro get their drinking water from wells, but some households purchase bottled water.

San Isidro was included in an earlier study, done between 1990 and 1995, that assessed the oral health conditions of a population $(\mathrm{N}=3700)$ living in south Texas. ${ }^{4}$ That study evaluated dentition status, fluorosis, and other conditions, using WHO criteria (9). At that time, samples of drinking water from wells in San Isidro supplying families of school children there showed fluoride concentrations ranging from 0.59 to 1.95 milligrams/liter (mg/L). Fluorosis data were assessed from 97 San Isidro children 6-17 years old using the Dean 0-5 scale (9). The data indicated that $59 \%$ of the children had a score of 0 (absence of any signs of fluorosis), $21 \%$ had a score of 1 or 2 (questionable or very mild fluorosis), $16 \%$ had a score of 3 (mild fluorosis), $4 \%$ scored 4 (moderate fluorosis), and none scored 5 (severe fluorosis).

\footnotetext{
4 Baez RJ, Baez MX. Oral health status in south Texas Mexico border [unpublished paper]; 1999.
}

These conditions, plus the fact that San Isidro water sources had not changed and fluoride concentration had remained constant for several years, served as the basis for selecting this community for our urinary fluoride excretion study. In addition, this community situation is similar to that of many other hot rural areas throughout the Americas.

San Isidro has only one school, a public school with 365 children enrolled from prekindergarten through high school. The children participating in our study were in prekindergarten (age 4 years or older) through the first grade of elementary school. The teachers for the age groups included in the study conduct one supervised toothbrushing every day with fluoridated toothpaste. The children have breakfast and lunch provided at the school. On the day that urine samples were taken at the school, the children ate and drank as usual at the school, and no efforts were made to influence either the type or quantity of foods or beverages the children received or consumed either at the school or at home after school hours.

Participation in the study was open to children attending the selected school who were 4-6 years old and who had lived in the area as permanent residents for at least the preceding two years. When we asked the parents of the 33 eligible students to grant permission for their children to participate, 31 families signed the required consent form and 2 declined.

We explained the purpose of the study and the urine collection procedures to the parents and to the school nurse and other school staff participating in the study. The nurse and the investigators instructed the parents on how to record the micturitions and collect their children's nocturnal urines. The parents also completed a short questionnaire on the types of food consumed on the study day and the preceding one, and on use of products for oral health care, many of which contain fluoride. The information from those questionnaires indicated that the children used fluoridated toothpaste and that their diet was not out of the ordi- 
nary and consisted of foods customary in south Texas.

During the school hours, urine was collected at the bathroom doorways, with male and female investigators at the school to supervise children of the corresponding gender. We noted the time of the first micturition but discarded the sample because it was not time controlled, that is, we did not know the time of the previous micturition. For each subsequent micturition in the morning we recorded the time and volume, until the children went to lunch. That morning time span comprised "Period A." The mean duration of Period A was 2.3 hours (standard deviation \pm 1.01 hours).

The collection process was repeated in the afternoon until the children were ready to leave school for the day. That "Period B" lasted a mean of 2.96 hours ( $\mathrm{SD} \pm 1.27$ hours).

During the remainder of the afternoon and the evening ("Period $C^{\prime \prime}$ ), urine was not collected. That was because during transport of the children in the school bus and their later "free" time, urine and micturition times would not have been obtained with satisfactory reliability.

We gave the children or their parents labeled plastic bottles to use for urine collection at home. The parents noted the time of last micturition before the child went to bed but did not collect this urine. This point in time marked the beginning of "Period D," of nocturnal collection. The nocturnal period lasted a mean of 9.68 hours $(\mathrm{SD} \pm 0.71$ hours). We also gave parents containers to collect drinking water samples for fluoride-concentration determination. Children or parents brought the nocturnal urine collections and the drinking water samples to the school and delivered them to the school nurse.

The volume of each urinary collection was determined and then approximately $30 \mathrm{~mL}$ of the collection was placed in a plastic cylinder containing $0.06 \mathrm{mg}$ of thymol preservative. The investigators placed the $30-\mathrm{mL}$ samples in a refrigerated container for transport to the dental school at the University of Texas Health Science Center at San
Antonio (UTHSCSA), where the laboratory analysis was done. All samples were frozen and were then tested 11 days later. The concentration of fluoride in $\mathrm{mg} / \mathrm{L}$ (ppm) was determined using a specific fluoride ion electrode (model 9609BN/290A, Orion Research, Beverly, Massachusetts). The total amount of fluoride $(\mu \mathrm{g} F)$ was divided by the duration (hours) of the collection period to calculate the excretion in $\mu \mathrm{g} \mathrm{F} / \mathrm{h}$. Similarly, the urinary flow was calculated as the $\mathrm{mL}$ of urine collected divided by the duration in hours, or $\mathrm{mL} / \mathrm{h}$. The UTHSCSA laboratory also tested the drinking water samples obtained in San Isidro to determine their fluoride concentrations.

\section{RESULTS}

The drinking water samples, which we received from 28 households, had a mean fluoride concentration of 1.32 $\mathrm{mg} / \mathrm{L}$, with a median of $1.30 \mathrm{mg} / \mathrm{L}$. The lowest quartile had concentrations between $0.1 \mathrm{mg} / \mathrm{L}$ and $0.56 \mathrm{mg} / \mathrm{L}$ (mean $0.26 \mathrm{mg} / \mathrm{L}$ ). The range for the highest quartile was from $1.81 \mathrm{mg} / \mathrm{L}$ to $3.22 \mathrm{mg} / \mathrm{L}$ (mean $2.53 \mathrm{mg} / \mathrm{L}$ ). The remaining half of the concentrations extended from $0.74 \mathrm{mg} / \mathrm{L}$ to $1.65 \mathrm{mg} / \mathrm{L}$ (mean $1.32 \mathrm{mg} / \mathrm{L}$ ). The water in the school comes from two wells located on the school grounds. The fluoride concentrations we found from various school water taps ranged from 1.0 $\mathrm{mg} / \mathrm{L}$ to $1.3 \mathrm{mg} / \mathrm{L}$.

Of the 31 children whose parents had given permission for them to participate, 2 did not attend school the day when urine was collected and were consequently excluded from the study. Of the remaining 29 children, 5 failed to hand in the nocturnal collection. In the resulting 82 available urines, the mean fluoride concentrations were $1.261 \mathrm{mg} / \mathrm{L}$ in the morning urines (24), $1.419 \mathrm{mg} / \mathrm{L}$ in the afternoon urines (29), and $1.334 \mathrm{mg} / \mathrm{L}$ in the nocturnal urines (29).

For 2 of the morning, 4 of the afternoon, and 8 of the nocturnal collections, times at micturition or the volume of urine were incompletely recorded. Setting aside those 14 collections with incomplete information, that left 68 "valid" collections to use in determining fluoride excretion.

Out of the full cycle of 24 hours, the duration of the collections added to 15 hours: 2.3 hours in the morning, 3.0 hours in the early afternoon, and 9.7 hours at night. The mean urine flow was $35.2 \mathrm{~mL} / \mathrm{h}$ in the morning, 38.2 $\mathrm{mL} / \mathrm{h}$ in the afternoon, and $13.5 \mathrm{~mL} / \mathrm{h}$ during the nocturnal period (Table 1). The two daytime means were considerably higher than the respective medians and were both due to a few very high results obtained from different subjects. Mean fluoride excretion rates were $36.4 \mu \mathrm{g} / \mathrm{h}$ in the morning, 45.6 $\mu \mathrm{g} / \mathrm{h}$ in the afternoon, and $17.5 \mu \mathrm{g} / \mathrm{h}$ in the night.

A complete set of valid morning, afternoon, and night collections were available from 15 of the 29 children. Within each of the collection periods, the statistics from this subsample of 15 children were similar to those for all valid collections (Table 1). The complete set of three collections from these 15 children allowed unbiased withinday comparisons. For these 15 "complete" children, the average of the morning and afternoon urinary flow was significantly higher than the nocturnal urinary flow $(P<0.002$ in the sign test). Similarly, their daytime fluoride excretion was significantly higher than the nocturnal level $(P<$ 0.001).

\section{DISCUSSION}

Other research has found that for persons living in temperate climates the concentration of fluoride in urine is similar to its concentration in those persons' drinking water (10). The range of urine fluoride concentrations we observed throughout the 24-hour period of our study, $1.26-1.42 \mathrm{mg} / \mathrm{L}$, confirms this rule for both daytime and nocturnal urine. Regarding the amount of fluoride excreted per hour, the nocturnal mean was less than the excretion in the morning and in the afternoon. This finding is in keeping 
TABLE 1. Urinary flow and fluoride excretion for all "valid" collections and for the "complete" collections from children 4-6 years old in a south Texas community, March 1997

\begin{tabular}{lrrr}
\hline & \multicolumn{3}{c}{ Collection period } \\
\cline { 2 - 4 } & Morning & Afternoon & Night \\
\hline Urinary flow (mL/h) & & & \\
Minimum & 10.8 & 10 & 6.1 \\
Maximum & 138.5 & 142.5 & 44.3 \\
Median & 17.5 & 28.4 & 11 \\
Mean & 35.2 & 38.2 & 13.5 \\
Standard deviation & 34.7 & 34.2 & 8.3 \\
Coefficient of variation (\%) & 99 & 90 & 61 \\
Median of the 15 "complete" collections & 16.1 & 24 & 10.4 \\
Mean of the 15 "complete" collections & 33.1 & 31.5 & 13.2 \\
& & & \\
Fluoride excretion ( $\mu$ g/h) & 11.6 & 11 & 4.2 \\
Minimum & 119.3 & 180.8 & 44.8 \\
Maximum & 27.4 & 31.9 & 17.1 \\
Median & 36.4 & 45.6 & 17.5 \\
Mean & 28.3 & 41.7 & 9.1 \\
Standard deviation & 78 & 91 & 52 \\
Coefficient of variation (\%) & 27.3 & 26.5 & 17.4 \\
Median of the 15 "complete" collections & 32.5 & 42.2 & 18.3 \\
Mean of the 15 "complete" collections & & & \\
\hline
\end{tabular}

a Valid collection = a collection for which complete field data were recorded (for the morning, afternoon, and night collection periods, the respective values were 22,25 , and 21 ).

${ }^{b}$ Complete collection = a complete set of three collections (morning, afternoon, and night) from a particular child. Fifteen such collections were obtained.

with the fact that glomerular filtration rate is a very important determinant of fluoride excretion, albeit not the only one (4).

When compared to the widely different fluoride concentrations found in the water at home, the $52 \%$ coefficient of variation of the nocturnal excretions seems fairly low (Table 1). The higher coefficients of variation at school $(78 \%$ in the morning, $91 \%$ in the afternoon) were obviously due to strongly vari- able amounts of food and water ingested, but with the fluoride concentrations in the servings at school being the same for all of the children.

Urine fluoride collections covering 15 hours provide fairly precise and accurate bases for extrapolations to the full diurnal cycle of 24 hours. Table 2 illustrates our application of this principle, which is based on guidelines from the World Health Organization (11) and uses the set of periods of 4,8 , and

TABLE 2. Illustration of extrapolations of fluoride excreted in 24 hours, south Texas, March 1997

\begin{tabular}{|c|c|c|c|c|}
\hline & Morning & Afternoon & Night & Total \\
\hline $\begin{array}{l}\text { Fluoride excretion }(\mu \mathrm{g} / \mathrm{h}) \text {, mean, all "valid" collections } \\
\text { (Table 1) }\end{array}$ & 36.4 & 45.6 & 17.5 & $N A^{a}$ \\
\hline $\begin{array}{l}\text { Period (hours) for World Health Organization standard } \\
\text { extrapolation }\end{array}$ & 4 & 8 & 12 & 24 \\
\hline Extrapolated amount of fluoride excreted $(\mu \mathrm{g})$ & 146 & 365 & 210 & $720^{b}$ \\
\hline
\end{tabular}

12 hours as a standard pattern. We assumed that the $36.4 \mu \mathrm{g} \mathrm{F} / \mathrm{h}$ excretion obtained from the supervised morning collections at the school during the mean 2.3-hour period was representative of the excretion for a morning period of 4 hours, for a result of $146 \mu \mathrm{g}$ fluoride excreted. Similarly, we extrapolated the afternoon mean of $45.6 \mu \mathrm{g}$ $\mathrm{F} / \mathrm{h}$ to 8 hours, resulting in $365 \mu \mathrm{g}$ fluoride excreted. Extrapolating the nocturnal mean of $17.5 \mu \mathrm{g} \mathrm{F} / \mathrm{h}$ resulted in $210 \mu \mathrm{g}$ fluoride excreted for a 12-hour period. Corrected for rounding error, our extrapolations for the three periods indicate that a total of $720 \mu \mathrm{g}$ fluoride was excreted during a full, 24hour-day cycle.

In order to assess possible inaccuracies associated with the extrapolations presented in Table 2, we computed two more series of extrapolations, using different subdivisions of the 24-hour period. The results are presented in Table 3 . Using all the valid collections, these two new extrapolation patterns resulted in total average excretions of $749 \mu \mathrm{g}$ fluoride and $777 \mu \mathrm{g}$ fluoride, as compared with the $720 \mu \mathrm{g}$ fluoride found with the first extrapolation.

As shown in Table 3, the difference between the lowest and the highest extrapolated averages for total fluoride excretion based on all valid collections were not substantial. This finding confirms other research (12). In contrast, there were much larger differences between the lower and upper confidence limits of each of the three extrapolations of total fluoride excretion based on all valid collections. This demonstrates that the statistical uncertainty due to the sampling variation was approximately six times higher than the bias in connection with the three different extrapolation patterns. When the extrapolations of the total fluoride excretion were based on the collections from the 15 "complete" children, the confidence intervals were almost 10 times larger than the difference between the lowest and highest averages from the three extrapolations.

From our results, Extrapolation 2 seems to be the most suitable of the 
TABLE 3. Three extrapolations of total 24-hour urinary flow and fluoride excretion, south Texas, for all "valid" collections and for "complete" collections, March 1997a,b,c

\begin{tabular}{|c|c|c|c|c|}
\hline & Average & $\begin{array}{l}\text { Standard } \\
\text { error }\end{array}$ & $\begin{array}{l}\text { Lower } \\
\text { confidence } \\
\text { limit }^{d}\end{array}$ & $\begin{array}{l}\text { Upper } \\
\text { confidence } \\
\text { limit }^{d}\end{array}$ \\
\hline \multicolumn{5}{|c|}{$\begin{array}{l}\text { Total urinary flow }(\mathrm{mL} / 24 \mathrm{~h}) \text {, based on } \\
\text { all "valid" collections }\end{array}$} \\
\hline WHO standard extrapolation & 608 & 73 & 451 & 766 \\
\hline Extrapolation 2 & 633 & 79 & 464 & 801 \\
\hline Extrapolation 3 & 657 & 84 & 477 & 838 \\
\hline \multicolumn{5}{|c|}{$\begin{array}{l}\text { Total urinary flow (mL/24h), based on } \\
15 \text { "complete" collections }\end{array}$} \\
\hline WHO standard extrapolation & 543 & 89 & 352 & 733 \\
\hline Extrapolation 2 & 561 & 95 & 357 & 765 \\
\hline Extrapolation 3 & 579 & 102 & 361 & 798 \\
\hline \multicolumn{5}{|c|}{$\begin{array}{l}\text { Total fluoride excretion }(\mu \mathrm{g} / 24 \mathrm{~h}) \text {, based on } \\
\text { all "valid" collections }\end{array}$} \\
\hline WHO standard extrapolation & 720 & 83 & 541 & 900 \\
\hline Extrapolation 2 & 749 & 90 & 557 & 941 \\
\hline Extrapolation 3 & 777 & 96 & 572 & 982 \\
\hline \multicolumn{5}{|c|}{$\begin{array}{l}\text { Total fluoride excretion }(\mu \mathrm{g} / 24 \mathrm{~h}) \text {, based on } \\
15 \text { "complete" collections }\end{array}$} \\
\hline WHO standard extrapolation & 688 & 101 & 470 & 905 \\
\hline Extrapolation 2 & 712 & 108 & 479 & 944 \\
\hline Extrapolation 3 & 736 & 116 & 487 & 984 \\
\hline
\end{tabular}

three extrapolations. Twelve hours of low nocturnal fluoride excretion (the period used in the first, WHO standard extrapolation) seems somewhat long for the San Isidro children studied. While the mean San Isidro nocturnal period was 9.7 hours, it is unlikely the fluoride excretion increased immediately after the morning micturition even when breakfast was taken within one half hour. For this reason, Extrapolation 2 seems more suitable. As expected, the extrapolations using all 68 available "valid" collections were more precise than the ones based on the 45 collections from the 15 "complete" children, with the first group having smaller differences between the lower and upper confidence limits. Accordingly, the best estimate for fluoride excreted in 24 hours comes from Extrapolation 2 using all valid collections. That value is $749 \mu \mathrm{g}$ fluoride, with confidence limits of $557 \mu \mathrm{g}$ and $941 \mu \mathrm{g}$. full potential of caries-protective fluoride is not being exploited. With excretions above $500 \mu \mathrm{g}$ the frequency of dental fluorosis would increase to levels beyond those now accepted by the public.

Used as a biomarker for fluoride exposure, excretion can identify groups at risk of fluorosis 3 to 5 years earlier than is possible by just studying fluorosis.

Slight fluorosis is generally accepted by the public (20). Mild fluorosis has been occurring for over two decades in about one-fourth of the children in which the secular decline of caries prevalence has been substantial (21). It is generally believed that mild fluorosis is preferable to the devastating effect of dental caries. And while high fluoride levels in the drinking water may be the main cause of fluorosis, other factors may play a role (22).

The modest fluorosis level found in the earlier study of San Isidro children is in line with a recommended water fluoride level for the community of $0.7 \mathrm{ppm}$, given the climate in southern Texas and applying the formula of Galagan and Vermillion (23).

Fluoride excretion in the San Isidro children was higher than for other children consuming water with 0.8 to $1.1 \mathrm{mg} / \mathrm{L}$ fluoride. However, the earlier study in San Isidro found no cases with severe fluorosis and only $4 \%$ of the cases with moderate fluorosis.

In order to minimize the risk of unsightly fluorosis in San Isidro and other communities with similar conditions, we suggest two easy measures: 1) using fluoride-free toothpastes at home and at school up to the age of 6 years and 2) using bottled water in households with children below the age of 6 years and where the well water has a fluoride level higher than $0.7 \mathrm{mg} / \mathrm{L}$.

The children who are 4 years or older will consume the water at the school, which has a fluoride level of $1.0-1.3 \mathrm{mg} / \mathrm{L}$. However, at this age the risk of causing fluorosis to the incisors is diminished or may have already ended. For the long-term benefit to the children's permanent teeth the fluoride contained in the school water is essential. 
TABLE 4. Urinary fluoride excretion of children 2-6 years of age who had been consuming drinking water fluoridated at different levels, studies in various countries

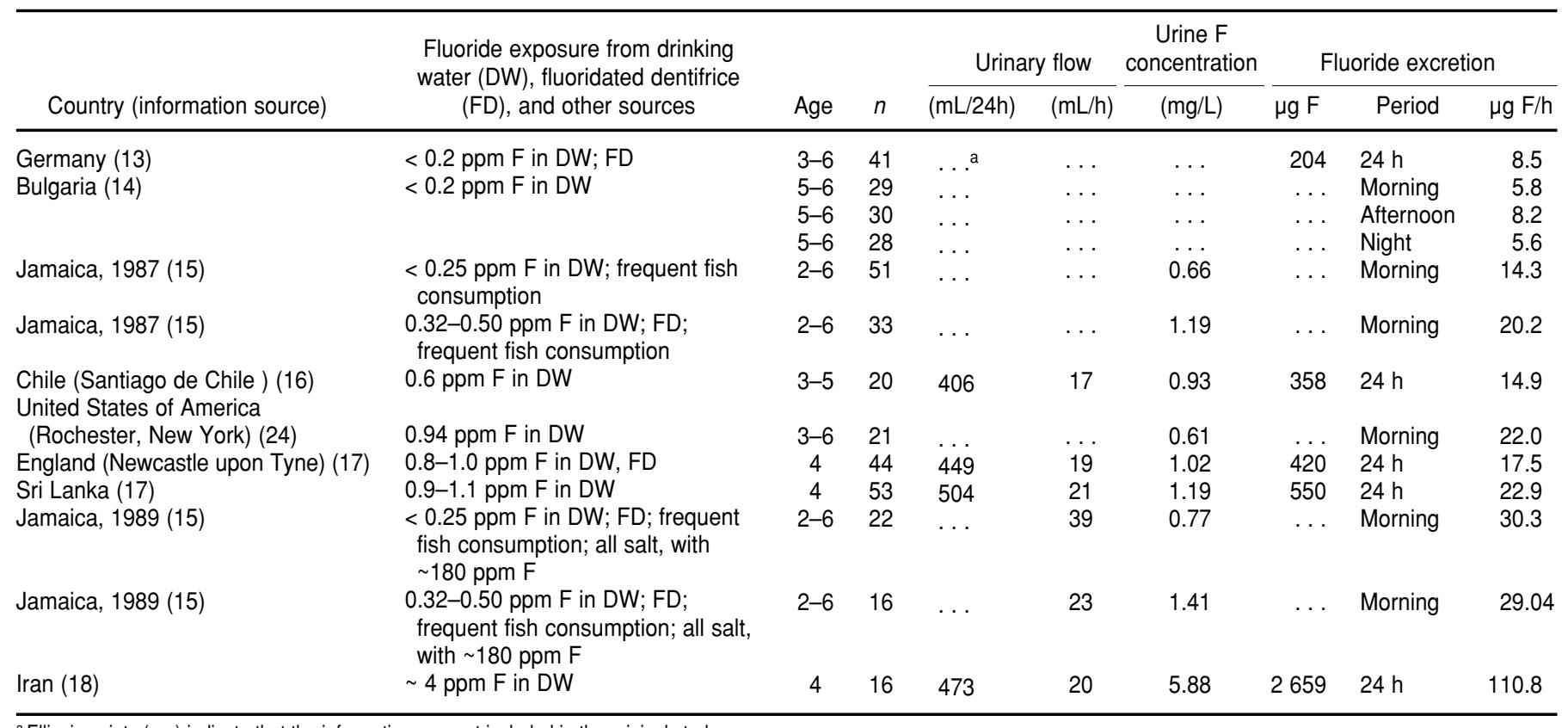

a Ellipsis points (...) indicate that the information was not included in the original study.

\section{REFERENCES}

1. World Health Organization. Fluorides and oral health. Geneva: WHO; 1994. (WHO Technical Report Series 846).

2. Fomon SJ, Ekstrand J. Fluoride intake. In: Fejerskov O, Ekstrand J, Burt BA, eds. Fluoride in dentistry. 2nd ed. Copenhagen: Munksgaard; 1996. p. 42-47.

3. Lewis DW, Banting DW. Water fluoridation: current effectiveness and dental fluorosis. Community Dent Oral Epidemiol 1994;22(3): 153-158.

4. Whitford GM. The metabolism and toxicity of fluoride. 2nd ed. New York: Karger; 1996.

5. Ekstrand J, Ehrnebo M. Studies on the relationship between plasma fluoride, urinary excretion rate and urine fluoride concentration in man. J Occup Med 1983;25:745-748.

6. Obry-Musset AM, Bettembourg D, Cahen PM, Voegel JC, Frank RM. Urinary fluoride excretion in children using potassium fluoride containing salt or sodium fluoride supplements. Caries Res 1992;26(5):367-370.

7. Marthaler TM, Steiner M, Menghini G, Sener $B$, De Crousaz P. Urinary fluoride excretion in children with low fluoride intake or consuming fluoridated salt. Caries Res 1995;29(1): 26-34.

8. Marthaler TM, Binder M, Baez RJ, Menghini G. Urinary fluoride excretion in Swiss children ages 3 and 4 consuming fluoridated domestic salt. Schweiz Monatsschr Zahnmed. Forthcoming 2000.

9. World Health Organization. Oral health survey. Basic methods. 3rd ed. Geneva: WHO; 1987.
10. Hodge HC, Smith FA, Gedalia I. Excretion of fluorides. In: World Health Organization. Fluorides and human health. Geneva: WHO; 1970. p. 141-161. (WHO Monograph Series No. 59).

11. Marthaler TM, ed. Guidelines for using excreted fluoride as a marker for the determination of bioavailable fluoride. Geneva: World Health Organization; 1999.

12. Marthaler TM, Menghini GD, Steiner M, Sener-Zanola B, De Crousaz P. Excreción urinaria de fluoruro en niños suizos que consumen suplementos de fluoruro en la sal o el agua. Archivos de Odontoestomatología Preventiva y Comunitaria 1992;24:27-35.

13. Schulte A, Stoll R, Pieper K. Fluoridkonzentration im Urin von Kinder mit unterschiedlicher Fluoridzufuhr. Dtsch Zahnartzl Z 1995; 50:49-52.

14. Marthaler TM, Phillips PC. Urinary fluoride in Bulgarian pre-school children after intake of fluoridated milk. J Dent Res 1994;73:178.

15. Warpeha R, Marthaler TM: Urinary fluoride excretion in Jamaica in relation to fluoridated salt. Caries Res 1995;29(1):35-41.

16. Villa A. The fractional urinary fluoride excretion in young children under stable fluoride intake conditions. Community Dent Oral Epidemiol. Forthcoming 2000.

17. Rugg-Gunn AJ, Nunn JH, Ekanajake L, Saparamadu KDG, Wright WG. Urinary fluoride in 4-year-old children in Sri Lanka and England. Caries Res 1993;27(6):478-483.

18. Zohouri FV. Fluoride intake and excretion in 4-year-old Iranian children [Ph.D. disserta- tion]. Newcastle, United Kingdom: University of Newcastle; 1997.

19. Rojas-Sanchez F, Kelly SA, Drake KM, Eckert GJ, Dunipace AJ. Fluoride intake from foods, beverages and dentifrices by young children in communities with negligibly and optimally fluoridated water: a pilot study. Community Dent Oral Epidemiol 1999;27(4):288-297.

20. Hawley GM, Ellwood RP, Davies RM. Dental caries, fluorosis and the cosmetic implications of different TF scores in 14-year-old adolescents. Comm Dent Health 1996;13(4):189-192.

21. Holloway PJ, Ellwood RP. The prevalence, causes and cosmetic importance of dental fluorosis in the United Kingdom: a review. Community Dent Health 1997;14(3):148-155.

22. Brothwell DJ, Limeback H. Fluorosis risk in grade 2 students residing in a rural area with widely varying natural fluoride. Comm Oral Epidemiol 1994;22:153-158.

23. Galagan DJ, Vermillion JR. Determining optimum fluoride concentrations. Public Health Rep 1957;72(6):491-493.

24. Drummond BK, Curzon MEJ. Urinary excretion of fluoride following ingestion of MFP toothpaste by infants aged two to six years. J Dent Res 1985;64(9):1145-1148.

Manuscript received on 30 August 1999. Revised version accepted for publication on 8 February 2000. 
RESUMEN Este estudio investigó la excreción urinaria de fluoruro en escolares de 4 a 6 años de edad residentes en una comunidad rural del sur de Texas donde las concentraciones de fluoruro en el agua potable se encuentran generalmente cerca del nivel óptimo.

Excreción urinaria de fluoruro en niños de cuatro a seis años de edad en una comunidad del sur de Texas
Bajo supervisión, en la escuela se recolectó la orina de la mañana y la tarde, y en el domicilio la de la noche. Se registraron el inicio y el final de los tres períodos de recolección y se determinaron el volumen de orina y el flujo urinario de cada período. Se midió la concentración de fluoruro en orina y se calculó la excreción urinaria por hora. Los niños tomaron el desayuno y el almuerzo en la escuela, donde el agua potable contenía 1,0 a 1,3 mg/L de fluoruro. En los domicilios, el agua, procedente de pozos, tenía concentraciones de fluoruro que oscilaron entre 0,1 y 3,2 mg/L. Las concentraciones urinarias medias diurnas y nocturnas de fluoruro fueron similares y oscilaron entre 1,26 y 1,42 mg/L. La excreción media fue de 36,4 $\mu \mathrm{g} / \mathrm{h}$ por la mañana, $45,6 \mu \mathrm{g} / \mathrm{h}$ por la tarde y $17,5 \mu \mathrm{g} / \mathrm{h}$ por la noche. La menor excreción nocturna se explica fácilmente por el menor flujo urinario nocturno. La excreción de fluoruro en 24 horas, extrapolada a partir de la orina recolectada en 15 horas, fue de $749 \mu \mathrm{g}$. Combinados con los datos de investigaciones similares, los resultados de este estudio contribuirán a establecer los límites superiores de la excreción de fluoruro que permitan evitar la fluorosis y, al mismo tiempo, proporcionen una protección óptima frente a la caries dental. 